\title{
Heinz Kimmerle's intercultural philosophy and the quest for epistemic justice
}

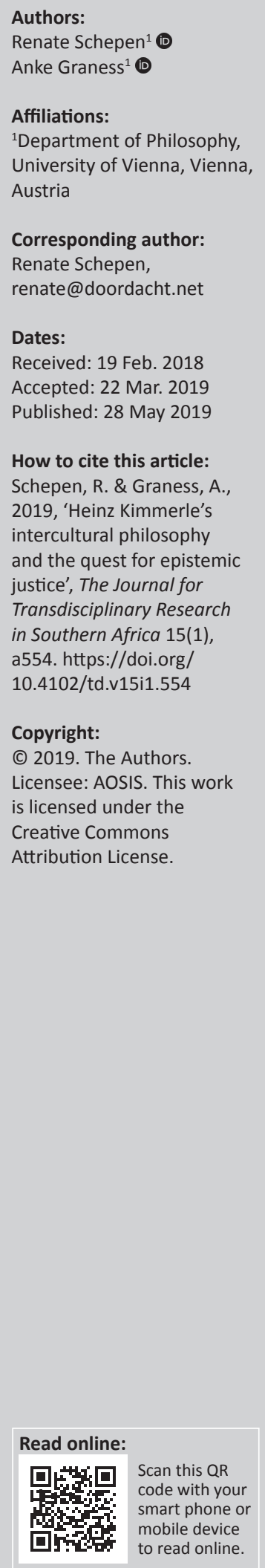

Since the 1990s epistemic (in)justice has been a central issue of post-colonial and feminist studies. But only during the last decade the term has become paradigmatic and new aspects of the issue have been addressed - particularly because of the works of De Sousa Santos $(2012,2014)$ and Fricker (2007). One of the pioneers of an intercultural approach to philosophy is the German philosopher Heinz Kimmerle (1930-2016), who in the 1980s began to focus his research on African philosophies. Intercultural philosophy aimed for more epistemic justice in the academy long before the term epistemic or cognitive injustice was coined and became a new paradigm in the social sciences and humanities. Kimmerle, for example, was one of the main proponents of a radical reform of the Eurocentric curricula in academic philosophy, and he called for the inclusion of philosophical traditions from various regions of the world. Similarities in the starting point of research and research questions in philosophy and post- or decolonial studies, and proposed solutions to epistemic injustice in these disciplines, give enough reason to combine the social sciences' theories of epistemic justice with the methods of intercultural philosophy for a reciprocal cultural enrichment between these disciplines. This article shows that theories of 'epistemic justice' could benefit from Heinz Kimmerle's method of dialogue and reflective listening. Similarly, insights derived from post-colonial, decolonial and feminist theory could strengthen an awareness of structural power inequalities in intercultural philosophy. Therefore, we explore how theories of epistemic justice and intercultural philosophy can complement each other.

Keywords: Intercultural philosophy; epistemic injustice; Heinz Kimmerle; feminist theory; difference.

\section{Introduction}

Currently, in the academic discipline of philosophy, 'Western'1 epistemologies are, undoubtedly, dominant. Although marginalised groups are occasionally the object of studies, their knowledge is hardly recognised as a contribution to - or even included in - academic philosophy, nor is this knowledge considered by policy-makers in dealing with global problems. However, in an increasingly globalised world, the realisation dawns that approaching global problems purely from a 'Western' perspective is neither effective nor justified.

A key task of intercultural philosophy is to challenge the dominant Anglo-American and Eurocentric paradigm of philosophy. An intercultural perspective presupposes that, regardless of the asymmetries of power in the world and in the academy, every tradition or school of thought is equally entitled to introduce ideas, concepts and questions to philosophical discourse, and that no force except that of the better argument should be exerted. By incorporating non-'Western' traditions into teaching and research, intercultural philosophy attempts to balance the presentday philosophical canon dominated by texts written by 'white men'. Thus, an intercultural perspective is characterised by a sincere effort to recognise the equality of theoretical contributions from different regions and traditions of the world and integrate them into an open discourse on various theoretical issues. It goes beyond a comparative juxtaposition, where the Other is taken as an exotic extra or a nice supplement to the 'true' theory or considered an object of study outside the main stream of philosophical thought. Therefore, the intercultural approach contributes to an open, plural discourse.

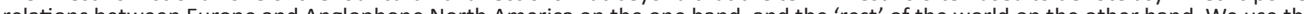
relations between Europe and Anglophone North America on the one hand, and the 'rest' of the world on the other hand. We use the term to mean the following. 'Western' denotes Europe and Anglophone North America, while 'non-Western' refers to all other parts of the world, today also called the 'Global South'. We are quite aware that such a usage is a reduction of the enormous heterogeneity of the 'non-Western' world in respect to culture, religion, history, language and, of course, the history of ideas. At the same time, it is a reduction of the 'West' as well. See, among others, Chandra Mohanty's discussion of the terms 'West' and 'Third World' or 'North' and 'South' (Mohanty 2003:505-507). 
However, to date, intercultural approaches to philosophy have received hardly any attention. 'Of the top 50 philosophy doctoral programs in the English-speaking world, only 15 percent have any regular faculty members who teach any non-“Western" philosophy' (Garfield \& Van Norden 2016). A study of 20 randomly selected universities in Germanspeaking countries found that the curricula of only a fifth of bachelor's programmes in philosophy proved to provide a firm foundation in the intercultural dimension of philosophy (Schirilla 2011). A recent study of curricula of departments of philosophy in Africa shows that very few of the continent's departments of philosophy offer courses on African philosophy (Etieyibo \& Chimakonam 2018).

But, as Boaventura de Sousa Santos warns, persistent denial of the validity of epistemologies from 'the South' and failure to acknowledge marginalised voices could lead to the disappearance of such epistemologies and ultimately even epistemicide, the murder of knowledge, caused by unequal exchanges among cultures (De Sousa Santos 2014:92). Feminist and post-colonial studies have offered critiques of such tendencies and their dangers, as has intercultural philosophy.

In this article, we will first offer a brief introduction to the recent debate on epistemic justice (De Sousa Santos 2014; Fricker 2007), and then examine issues of epistemic justice through the lens of African philosophers such as Mogobe Ramose (1999), Sophie Oluwole (2014) and Henry Odera Oruka (1990). Next, we will elaborate on Heinz Kimmerle's intercultural philosophy, focussing on the period between 2006 and 2016. Although his former work has been extensively researched (De Schipper 2013; Oosterling 1993, 2005; Oosterling \& Jong 1990), to date this latter period has rarely been studied. We will delineate his main motivations and method, and then describe the new perspectives offered by his theory, which, we argue, will enhance intercultural philosophy and dialogue. Finally, we will explore how intercultural philosophy and theories of epistemic justice complement each other, and conclude that even though Kimmerle did not use the term 'epistemic justice', his theory inherently demands epistemological diversity and justice.

An intercultural perspective presupposes that every tradition or school of thought is equally entitled to introduce ideas, concepts and questions to the global philosophical discourse, and that all the participants in such discussions are motivated only by a concern for the better argument. This means that we, European female scholars, should be aware of our own contextuality, and how it is reflected in our thinking, even though we cannot (and do not want to) escape our location and rootedness in the 'Western' academy. Being female philosophers also offers an epistemic privilege, by providing the ability to reflect from a marginalised position in the 'Western' academic discourse on this very discourse. For example, it must be questioned whether the given form of academic publication does not restrict or even render impossible the presentation of previously marginalised traditions. The injustice done, when epistemologies are omitted from academic discourse, already starts with the established scientific forms of presentation. We hope that this article promotes openness to different epistemologies and related methods of philosophising.

\section{Epistemic justice and epistemological diversity}

The works of De Sousa Santos $(2012,2014)$ and Miranda Fricker (2007, 2013), which have contributed to the development of a new paradigm in social sciences, have particularly been influential in the discourse on epistemic justice. Although De Sousa Santos approaches the issue from the point of view of the neglected epistemologies of the South, Fricker's approach originates in political philosophy and feminist theory.

Fricker considers epistemic injustice a distinctive type of injustice, which she theorises as 'consisting, most fundamentally, in a wrong done to someone specifically in their capacity as a knower' (Fricker 2007:1). She distinguishes two types of epistemic injustice, both discriminatory and driven by a form of prejudice. Testimonial injustice is related to a broader pattern of injustice in which a collective social imagination creates social identities considered to have less credibility, for example, the idea that women are irrational and black people are intellectually inferior (Fricker 2007:23). Hermeneutical injustice concerns the notion that, from an epistemological point of view, the powerful have an unfair advantage in structuring collective understanding and creating collective social meanings. This occurs predominantly in professions such as journalism, politics, academics and law. To correct these two forms of epistemic injustice, Fricker suggests a reflexive awareness on the part of the hearer (Fricker 2007:169). For this, the role of dialogue is vital, as it will enable the virtuous hearer to create a more inclusive hermeneutical micro-climate. This type of dialogue involves a more proactive and socially aware kind of listening, in which one not only listens to what is said, but also to what is not said. If the speaker and hearer share little relevant social experience, this might be very difficult; it might demand more effort from the hearer to find ways to understand the immanent meaning in the message of the speaker. If this is not possible, the virtue of hermeneutical justice may simply lie in the reservation of judgement and keeping an open mind as to credibility (Fricker 2007:171-172).

Fricker is aware that hermeneutical marginalisation is mostly caused by unequal power relationships; however, in her book Epistemic Injustice (2007), her prime concern is the individual's virtue of hermeneutical justice, which could mitigate the negative effect of hermeneutical injustice on a speaker (Fricker 2007:175). In the case of inequalities of social power, the justice referred to is structural, but Fricker suggests corrective measures based on individual virtues. Furthermore, her main concern here is discriminatory injustice and not distributive injustice, which is related to the distribution of epistemic goods such as education or information. She does 
not consider distributive injustice as distinctly epistemic injustice because distributive justice is about everybody getting a fair share of goods. That it concerns epistemic goods in this case is only incidental (Fricker 2007:1).

In her critique of Fricker, Nancy Fraser argues that, if epistemic injustice is structural, more than individual virtues are needed to correct epistemic injustice; there is a need for social and institutional change. Fraser suggests both changing institutions that are relevant for shaping epistemologies and also creating counter-discourses and alternative ways of knowledge formation. The institutions she refers to are political institutions, the media and the educational system (Fraser 2008). In her later work, Fricker too considers addressing distributive injustice to be as relevant as addressing discriminatory injustice to correcting epistemic injustice (Fricker 2013:1317-1332). She argues that there is not only a need for individual virtues of epistemic justice, but that these virtues need to be practised at an institutional level.

Although De Sousa Santos and Fricker both address injustice related to epistemic practices, they do not refer to one another's works. Fricker places the focus on the knower who is not recognised as such; De Sousa Santos' approach is slightly different. He uses the term cognitive injustice to refer to situations in which whole cultures or traditions of knowledge are marginalised or disregarded, to the point of disappearance. He criticises the unequal distribution of scientific knowledge based on colonisation and neo-colonialism, which granted disproportionate access to knowledge to certain social groups. Moreover, cognitive injustice does not refer only to scientific injustice, but also to the recognition of alternative forms of knowledge and to engagement with these forms of knowledge on an equal basis. Cognitive justice can be achieved by making plural epistemologies of scientific practices visible and promoting interdependence between scientific and nonscientific forms of knowledge (De Sousa Santos 2012:57).

De Sousa Santos (2012) makes a plea for epistemological diversity, and argues that:
... the theories produced in the Global North are best equipped to account for the social, political and cultural realities of the Global North and that in order adequately to account for the realities of the global South other theories must be developed and anchored in other epistemologies. (p. 45)

De Sousa Santos' assertion implies that intercultural dialogues comprise other kinds of knowledge: 'as conversations and partners in conversation change, the character of both changes as well, which may lead to infinite discursive and nondiscursive exchanges' (De Sousa Santos 2014:15).

Moreover, De Sousa Santos states that global social justice is not possible without global cognitive justice, a dimension rarely acknowledged in the discourse on global justice today (see Graness 2015). De Sousa Santos (2014) strongly criticises the failure to recognise that, in this world, people have different ways of knowing and of giving meaning to their existence.
Predecessors who advocated such an approach include Michel Foucault (1966), Gayatri Chakravorty Spivak (1988) and Chandra Talpade Mohanty (1984). Foucault has shown that there have been radical breaks within the dominant 'Western' episteme (Foucault 1966). For him, episteme refers to that which 'knowledge' and 'science' (savoir) entail in a certain time frame, and to the manner in which things are seen in their amalgamation (Leezenberg \& De Vries 2001). De Sousa Santos (2012) states that:

Foucault's great merit was to have shown the opacities and silences produced by modern science, granting credibility to alternative 'regimes of truth', other ways of knowing that had been marginalised, suppressed and discredited by modern science. (p. 63)

However, even though Foucault contributed immensely to disarming the imperial North epistemologically, he was not aware of other knowledges and experiences in the South (De Sousa Santos 2012:63). In 1988, Spivak offered a critique of Foucault, where she claims that the 1972 conversation between Foucault and Gilles Deleuze regarding intellectuals and power hides an essentialist agenda, which denies the heterogeneity of the subaltern (Spivak 1988:67-111). Based on a case study of African philosophy, De Sousa Santos distinguishes between internal plurality of knowledges, which are variations within the same general kind of knowledges, and external plurality of knowledges: a plurality among different kinds of knowledges (De Sousa Santos 2014:202). African philosophy is so different from conventional philosophy that De Sousa Santos considers this as an instance of external plurality (De Sousa Santos 2014:204). He illustrates it with the examples of Kwasi Wiredu $(1990,1996)$, who claims that Descartes' concept of cogito ergo sum cannot be translated into his mother tongue Twi, and Odera Oruka's Sage Philosophy (Odera Oruka 1990:203-204). Odera Oruka has demonstrated in his Sage Philosophy project that oral traditions can be philosophical and rational (Odera Oruka 1990). A similar example, not mentioned by De Sousa Santos, is Sophie Oluwole's comparative study of Socrates and Orunmila, which shows the philosophical relevance of oral knowledge traditions (Oluwole 2014). Oluwole argues that the translation of orally transmitted texts of Orunmila, according to the worldview and in the language of the coloniser, resulted in the transformation of the philosopher Orunmila into a mythical figure and the denial of the philosophical argumentation in his orally transmitted works. The South African philosopher Mogobe B. Ramose distinguishes between philosophy as practised in academia and 'philosophy as rational and critical engagement with the prevailing reality', and considers both approaches to philosophy equally valid (Ramose 2015:551-558). Moreover, Ramose underlines that the denial of African epistemologies is not merely a 'Western' academic practice, but that the 'Western' epistemological paradigm underlies the current educational system in Africa, too. Philosophy taught at African universities was (and still is in many universities) decontextualised and therefore not relevant to the 'experience of being-an-African in Africa' (Ramose 2005:28). Ramose also 
refers in his argument to feminist epistemologies, which previously demonstrated that so-called objectivity is in reality a universalisation of the subjective experience of men. Hence, the struggle in Africa should aim to both demasculinise and deracialise intellectual discourse (Ramose 2005:10). This struggle continues today, as evidenced by the 'Rhodes Must Fall' movement, which started in 2015 in Cape Town, and attempts to address the unequal vision of the world that is manifested within universities (Chaudhuri 2016).

\section{Heinz Kimmerle's intercultural philosophy and the 'in-between'}

The German philosopher Heinz Kimmerle (1930-2016) contributed tremendously to the quest for epistemic justice, even though he did not use the term. From 1988, he focussed especially on African philosophy and visited the African continent yearly till 2005, and stayed there for several months at a time to conduct long-term research and deliver guest lectures at various universities. As one of the few 'Western' philosophers of his time who demonstrated respect for the value of African philosophy, he was very familiar with the works of modern African philosophers, as is well documented in various of his publications (see e.g. Kimmerle 1994, 2005a). He referred frequently to the Sage Philosophy project of the Kenyan philosopher Henry Odera Oruka (1990), wrote the foreword for Philosophy and Oral Tradition by the Nigerian philosopher Sophie Oluwole (1999) and had many dialogues with the South African philosopher Mogobe B. Ramose.

Kimmerle was a strong critic of the Eurocentric discourse in academic philosophy. As early as 1978, Kimmerle stated that the method of philosophy and its production of values and norms are determined by a community of researchers, subject to geographical and temporal limitations (Kimmerle 1978:92). For him, the relation between cultures ${ }^{2}$, which has been determined from a Eurocentric perspective since the Enlightenment, has to be readjusted. He considers this 'one of the main problems of our time on which the possibility of a humane and dignified life partly depends', and states that 'in today's world philosophy will be intercultural or it will be nothing else than an academic activity without social relevance' (Kimmerle 1994:131).

Kimmerle's intercultural approach to philosophy draws from Gadamers' and Schleiermacher's hermeneutics; the dialectics of Hegel, Marx and Ernst Bloch; and the theory of différance developed by Derrida and Luce Irigaray (Oosterling 2005; Oosterling \& Schepen 2016). In contrast to intracultural dialogues (i.e. dialogues within one's own philosophical tradition), in which Gadamer sees a fusion of horizons, in intercultural dialogues such a fusion is neither possible nor desirable. Here, philosophical traditions other than one's own will always remain 'different'. But even philosophies from one's own tradition can never be completely known.
The work of philosophers of difference, especially that of Derrida and Irigaray, forms an important stepping stone for Kimmerle's acknowledgement of 'the otherness of the other' in his intercultural philosophy (Kimmerle 2000:48-49). For Kimmerle, there is an affinity between the philosophy of (sexual) différance and intercultural philosophy, for example, with regard to Irigaray's philosophy of difference, where mutual respect between the sexes is central, even though the sexes remain insurmountably different. Kimmerle considers postmodern and feminist thinkers' concept of différance to be a foundational concept for intercultural philosophy (Kimmerle 2011:137-151).

During his first phase of studying African philosophy, Kimmerle mainly focussed on listening to, learning from and understanding the philosophies of that continent. The year 2006 marks a turning point; it is a moment of 'return to one's own', as he calls it (Rückkehr ins Eigene is the title of his book in German). In the book Rückkehr ins Eigene, he started to reflect on the way his own thinking changed after he studied the philosophies of another continent. These studies inspired him to read European philosophical works from an intercultural perspective and to rethink certain aspects in the work of Hegel, Kant (Kimmerle 2010) and Derrida (Kimmerle 2005b). Thus, Kimmerle, a Hegel specialist and editor of volumes 5 through 9 of the historical-critical edition of Hegel's Collected Works, became a critic of Hegel's denial of African history and philosophy (Hegel 2001:110-111, 117). Moreover, Kimmerle addresses the need 'for a dynamic reservoir of possibilities of thinking that we can refer to for the solution of future problems not yet known to us' (Kimmerle 2006a:51). Parallels can be drawn between this 'dynamic reservoir of possibilities of thinking' and the present-day quest for 'epistemological diversity'. Kimmerle concluded that the concept of philosophy in itself has to change to become more intercultural.

The method Kimmerle suggests for intercultural philosophy is dialogue between equal partners. He argues that 'intercultural philosophical dialogues presuppose that the philosophies of all cultures are equivalent in rank and different in style as well as in content' (Kimmerle 2011:137-162). In addition to dialogues where 'Western' and non-'Western' traditions of philosophy are considered to have equal weight, Kimmerle also suggests specific dialogues to counter Eurocentric discourse, such as South-South-dialogues or dialogues between Chinese and African philosophies (Kimmerle \& Van Rappard 2011). However, the geographic reference remains problematic, as Europe is still the obvious centre from which the location of the dialogue partners is determined (Schepen \& Van Rappard 2019).

In 2006, Kimmerle published an article in The Journal of Transdisciplinary Research on the importance of animism, particularly for an ecological ethics, that demonstrates the inclusion of different epistemic paradigms in philosophical discourse (Kimmerle 2006b). In that article, Kimmerle, referring particularly to the works of Appiah (1992) and Oluwole (1991), shows that the quest to determine the 
existence and nature of a reality not perceivable by the human senses (like spirits) is omnipresent in African philosophies. Oluwole argues that 'Western' epistemological conceptions do not accept an explanation as reliable if it is not underpinned by sense data. However, she points out, in advanced sciences, such as quantum mechanics, the criteria by which knowledge is judged to be reliable have changed. Oluwole concludes that, in light of modern European science, belief in phenomena that cannot be perceived by the senses might more likely reflect truth than an epistemology based on materialism or empiricism. Kimmerle argues in his article that the belief in spirits has not completely disappeared in the 'West', but that it still plays an important role in the subconscious. However, it seems that 'for Western people the organ has become stunted by which the reality of spirits can be perceived' (Kimmerle 2006b:250). Referring to such concepts as Derrida's 'spectrology' (1993), Kimmerle demonstrates that in 'Western' philosophy spirits play an important role.

As he states, his motivation for writing this article was a conversation with Derrida in 1994 in Amsterdam. When he confronted Derrida with the idea that Derrida's spectrology excludes those spirits present in nature, Derrida admitted that his theory needed to account for those spirits, and he challenged Kimmerle to extend spectrology to include them (Kimmerle 2006b:257). Kimmerle tries to prove that a certain type of rationality in mainstream philosophy pushed the intrinsic value of nature to the background. By relating what he learned from African philosophers (Workineh Kelbessa and Wangari Maathai, among others) to his own tradition of philosophy, Kimmerle extrapolates Derrida's formulation of 'absently present' spirits (Derrida located such 'absently present' spirits in philosophy, art and literature by referring to Marx's Communist Manifesto and the spectre of communism or Shakespeare's Hamlet; their presence can be felt only in their absence) to spirits dwelling in nature (Kimmerle 2006b:256-257), and he concludes that the belief that all natural phenomena can be a dwelling place of spirits can be an important resource for environmental protection.

\section{Conclusion}

\section{The potential of relating epistemic justice and intercultural philosophy}

Discussions about epistemic justice share with discussions about intercultural approaches to philosophy the need to give the epistemological and philosophical contributions of all the world's cultures and traditions equal attention. Considering works discussing epistemic justice and works concerning intercultural approaches to philosophy alongside one another could enrich the understanding of both discussions and contribute to their common goal of promoting the recognition that the contributions of all cultures and traditions should be given equal weight in all intellectual discourse. We argue that relating works from two different approaches, such as decolonial or post-colonial theory and intercultural philosophy, could not only elucidate and enrich the content of both, but also reveal the limitations of those discussions.
For example, a critical re-reading of Kimmerle's approach to African and intercultural philosophy (as set forth, e.g., in Kimmerle 2006a, 2007) through the lenses of Fricker's critique of epistemic injustice $(2007,2013)$ and De Sousa Santos' concept of cognitive injustice $(2012,2014)$ reveals that, although Kimmerle does not explicitly name these forms of injustice, his theory anticipates the concepts and takes them into account. Fricker's and De Sousa Santos' discussions present ideas that make explicit the implications present, but not named in Kimmerle's work. They draw attention to the role of academia and the privileged position of 'Western' philosophers by showing how the powerful have an unfair advantage in structuring the collective understanding and creating collective social meanings. By considering Kimmerle's, Fricker's and De Sousa Santos' works alongside one another, 'Western' philosophers might grasp that a critique of the dominant 'Western' discourse has to start with reflection on our own dominant position in the academy and an awareness of the need for counterhegemonic strategies.

Another example of the way works on intercultural philosophy and epistemic justice may augment each other may be found in their use of dialogue. Dialogue holds a key role in both Heinz Kimmerle's work on intercultural approaches to philosophy and Miranda Fricker's work on epistemic justice (Fricker 2007:171; Kimmerle \& Schepen 2014). Heinz Kimmerle considers dialogue the most suitable method for intercultural philosophy (Kimmerle \& Schepen 2014). For Fricker too, the appropriate kind of dialogue can contribute to a more inclusive hermeneutical micro-climate (2007:171). A comparison of Kimmerle's and Fricker's arguments can offer new perspectives on the method of dialogue in intercultural philosophy.

In her later work, Fricker addresses structural power inequalities that cannot be resolved merely through the individual virtue of a careful listener (Fricker 2013). Kimmerle's dialogic method does not account for institutional and historical power relationships, so Fricker's work on epistemic justice could enrich Kimmerle's intercultural approach to philosophy by contributing an enhanced understanding of the pre-existing structural power inequalities, which provide the material and framework of any dialogue, and by pointing out the need for ongoing awareness of them. Part of such an awareness involves critiquing the role of educational institutions in knowledge production and questioning which narratives will be reproduced. In his work, Kimmerle addresses the nature of a just dialogue, which, he holds, has to start with both parties carefully listening to each other. In describing what an effective dialogue entails, Kimmerle's intercultural approach to philosophy offers a critical hermeneutical method of understanding and hearing, which allows for the difference and plurality of the 'other', a method that may be applied when addressing the structural epistemic injustice Fricker's theory describes.

A final example of the benefits of connecting theories of intercultural philosophy with theories of epistemic justice 
shows that doing so not only offers possibilities for exploring the intersection of systems of exclusion, but also guides us to possible alliances (Schepen 2018). Kimmerle's cooperation with Luce Irigaray made him aware of a strong affinity between philosophies of difference and intercultural philosophy. Likewise, in his work De Sousa Santos demonstrates how the alliance between different social movements can deepen the counter-hegemonic potential of both; as an example, he refers to the Zapatista movement's tendency to choose female rather than male leaders (De Sousa Santos 2012:43-47). In doing so, he makes a connection that escaped Kimmerle's notice; while Kimmerle addressed the marginalisation of African philosophy, he did not address the marginalisation of women in African philosophy (about the role of women in African philosophy see Chimakonam \& Du Toit 2018).

According to Kimmerle, for the discipline of philosophy to become intercultural, other forms of knowledge, such as oral traditions or spirituality, should be acknowledged as valid contributions to philosophical discussions. Furthermore, he relates what he learned from African philosophies to his own philosophical tradition. Thereby, he brings hidden aspects of 'Western' philosophies to the foreground, and elucidates what was obscured during the Enlightenment, but always remained present. In this way, Kimmerle makes us aware of the exclusion of other epistemologies during the Enlightenment period. This does not only do justice to epistemologies of the South, but also to the plurality in 'Western' philosophies. Recognising this plurality within philosophical traditions could promote both a deeper understanding of one's own philosophical tradition and openness to difference and plurality in 'others'.

\section{Acknowledgements}

Open access funding provided by University of Vienna.

\section{Competing interests}

The authors declare that they have no financial or personal relationships that may have inappropriately influenced them in writing this article. The views and opinions expressed in this article are those of the authors and do not necessarily reflect the official policy or position of any affiliated agency of the authors.

\section{Author's contributions}

The idea and structure of the article is based on the work of R.S. The text was written in close exchange with Dr A.G., who is the supervisor of the $\mathrm{PhD}$ research project of R.S.

\section{References}

Appiah, K., 1992, In my father's house: Africa in the philosophy of culture, Oxford University Press, New York.

Chaudhuri, A., 2016, 'The meaning of Rhodes must fall,' The Guardian, 16 March

Chimakonam, J.O. \& Du Toit, L. (eds.), 2018, African philosophy and the epistemic marginalization of women, Routledge, New York.
Derrida, J., 1993, Spectres de Marx: L'Etat de la dette, le travaille du deuil et la nouvelle Internationale, Galilée, Paris.

De Schipper, E., 2013, 'Way of thinking, thinking of way(s)', in M.B. Ramose (ed.), Hegel's twilight: Liber Amicorum Discipulorumque Pro Heinz Kimmerle, pp. 15-29, Studies in Intercultural Philosophy 23, Rodopi, Amsterdam.

De Sousa Santos, B., 2012, 'Public sphere and epistemologies of the south', Africa Development 37(1), 43-67.

De Sousa Santos, B., 2014, Epistemologies of the south: Justice Against Epistemicide, Routledge, New York.

De Sousa Santos, B. \& Ramose, M.B., 2014, 'Conversations of the world', ALICE: Strange Mirrors, Unexpected Lessons, Part 1, University of Coimbra Centre for Social Studies, Portugal, viewed from https://www.youtube.com/watch?v= UEDNoZg3G4Y

Etieyibo, E.E. \& Chimakonam, J.O., 2018, 'The state of African philosophy in Africa', in E.E. Etieybo (ed.), Method, substance, and the future of African philosophy, pp. 71-90, Palgrave Macmillan, Cham.

Foucault, M., 1966, Les mots et les choses (Une archéologie des sciences humaines), Gallimard, Paris.

Fraser, N., 2008, Adding insult to injury: Nancy Fraser debates her critics, K. Olson (ed.), Verso, New York.

Fricker, M., 2007, Epistemic injustice: Power and the ethics of knowing, Oxford University Press, Oxford.

Fricker, M., 2013, 'Epistemic justice as a condition of political freedom?' Synthese 190(7), 1317-1332. https://doi.org/10.1007/s11229-012-0227-3

Garfield, J.L. \& Van Norden, B.W., 2016, 'If philosophy won't diversify, let's call it what it really is', New York Times, 11 May.

Graness, A., 2015, 'Is the debate on global justice a global one? Some considerations in view of modern philosophy in Africa', Journal of Global Ethics 11(1), 126-140. https://doi.org/10.1080/17449626.2015.1010014

Hegel, G.W.F., 2001, The philosophy of history, transl. J. Sibree, Batoche Books, Kitchener, ON, viewed from http://www.efm.bris.ac.uk/het/hegel/history.pdf.

Kimmerle, H., 1978, Philosophie der Geisteswissenschaften als Kritik ihrer Methoden, Springer, Den Haag.

Kimmerle, H., 1994, Die Dimension des Interkulturellen: Philosophie in Afrika Afrikanische Philosophie. Zweiter Teil: Supplemente und Verallgemeinerungsschritte. Studien zur interkulturellen Philosophie 2, Rodopi, Amsterdam.

Kimmerle, H., 2000, Philosophien der Differenz: Eine Einführung, Köningshausen \& Neumann, Würzburg.

Kimmerle, H., 2005a, Afrikanische Philosophie im Kontext der Weltphilosophie, Traugott Bautz Verlag, Nordhausen.

Kimmerle, H., 2005b, Jacques Derrida interkulturell gelesen, Traugott Bautz Verlag, Nordhausen.

Kimmerle, H., 2006a, Rückkehr ins Eigene. Die interkulturelle Dimension in der Philosophie, Traugott Bautz Verlag, Nordhausen.

Kimmerle, H., 2006b, 'The world of spirits and the respect for nature: Towards a new appreciation of animism', The Journal for Transdisciplinary Research in Southern Africa 2(2), 15. https://doi.org/10.4102/td.v2i2.277

Kimmerle, H., 2007, Das Eigene-Anders Gesehen: Ergebnisse interkultureller Erfahrungen, Interkulturelle Bibliothek 48, Traugott Bautz Verlag, Nordhausen.

Kimmerle, H., 2010, Vernunft und Glaube im Gleichgewicht: Ein philosophischer Lebensweg, Verlag Karl Alber, Freiburg.

Kimmerle, H., 2011, 'Practical aspects of intercultural philosophy', in H. Oosterling \& E.P. Ziarek (eds.), Intermedialities: Philosophy, arts, politics, Textures: Philosophy/ Literature/Culture, pp. 137-162, Lexington Books, Lanham, MD.

Kimmerle, H. \& Schepen, R., 2014, Filosofie van het verstaan, Garant, Antwerp.

Kimmerle, H. \& Van Rappard, H., 2011, Afrika en China in dialoog: filosofische zuidoost dialogen vanuit westers perspectief, Garant, Antwerp.

Leezenberg, M. \& DeVries, G., 2001, Wetenschapsfilosofie Voor Geesteswetenschappen, Amsterdam University Press, Amsterdam.

Mohanty, C.T., 1984, 'Under western eyes: Feminist scholarship and colonial discourses', Signs: Journal of Women in Culture and Society 12(3) and 13(1), 333-358.

Mohanty, C.T., 2003, “'Under Western eyes" revisited: Feminist solidarity through anticapitalist struggles', Signs: Journal of Women in Culture and Society 28 (2), 499-535. https://doi.org/10.1086/342914

Odera Oruka, H., 1990, Sage philosophy: Indigenous thinkers and modern debate on African philosophy, Brill, Leiden.

Oluwole, S., 1991, Witchcraft, reincarnation and the god-head: Issues in African philosophy, Excel Publications, Lagos.

Oluwole, S., 1999, Philosophy and oral tradition, Ark Publishers, Lagos.

Oluwole, S., 2014, Socrates and Orunmila: Two patron saints of classical philosophy, Ark Publishers, Lagos, Nigeria.

Oosterling, H., 1993, 'Heinz Kimmerle: Een Porträt von Henk Oosterling', Information Philosophie 3(July), 32-36.

Oosterling, H., 2005, Interkulturalität im Denken Heinz Kimmerles, Traugott Bautz Verlag, Nordhausen.

Oosterling, H. \& De Jong, F., 1990, Denken Unterwegs: Philosophie im Kräftefeld sozialen und politischen Engagement. Festschrift für Heinz Kimmerle zu seinem 60, Geburtstag, B.R. Grüner Verlag, Amsterdam. 
Oosterling, H. \& Schepen, R., 2016, 'Nieuwe wegen in een intercultureel landschap. Het daadwerkelijke doordenken van Heinz Kimmerle (1930-2016)', Filosofie 2(March/April), 38-42.

Ramose, M., 2005, African philosophy through Ubuntu, Mond Book Publishers, Harare, Zimbabwe.

Ramose, M., 2015, 'On the contested meaning of philosophy', South African Journal of Philosophy 34(4), 551-558. https://doi.org/10.1080/02580136.2015. 1124509

Schepen, R., 2018, 'Dialogues and alliances: positions of women in African philosophy', in J.O. Chimakonam \& L. Du Toit (eds.), African philosophy and the epistemic marginalization of women, pp. 74-88, Routledge, New York.
Schepen, R. \& Van Rappard, H., 2018, 'Afrika und China im Dialog: Philosophische Süd-Ost-Dialoge aus westlicher Sicht', Philosophy East and West. A Quarterly of Comparative Philosophy 68(4), 1369-1379.

Schirilla, N., 2011, 'Interkulturelles Philosophieren im Studium der Philosophie', Polylog. Zeitschrift für interkulturelles Philosophieren 25, 31-38.

Spivak, G.C., 1988, 'Can the subaltern speak?' in C. Nelson \& L. Grossberg (eds.) Marxism and the interpretation of culture, pp. 67-111, Macmillan, London.

Wiredu, K., 1990, 'Are there cultural universals?', Quest 4(2), 5-19. https://doi.org/ $10.5840 /$ monist199578110

Wiredu, K., 1996, Cultural universals and particulars: An African perspective, Indiana University Press, Bloomington, IN. 